\title{
Member States, International Organizations and International Responsibility
}

\section{Exploring a Legal Triangle}

\author{
Ana Sofia Barros \\ Ph.D Researcher, Leuven Centre for Global Governance Studies, \\ University of Leuven \\ sofia.barros@ggs.kuleuven.be \\ Cedric Ryngaert \\ Professor of Public International Law, Utrecht University \\ C.M.J.Ryngaert@uu.nl
}

\section{Jan Wouters}

Director of the Leuven Centre for Global Governance Studies and the Institute for International Law, Professor of International Law and the Law of International Organizations, University of Leuven

jan.wouters@ggs.kuleuven.be

International organizations are complex, composite legal entities. They have been established by States but, endowed with separate international legal personality, aspire to lead an autonomous life at arm's length from their creators. Nevertheless, in order to properly carry out the normative and operational mandate allotted to them, they tend to rely, at least partly, on their member States: for example when performing military operations, or imposing sanctions against terrorists. In addition, member States continue to play a prominent role in institutional decision-making, as most, if not all, international organizations possess organs in which the member States - or a number of them - decide on action to be taken. This 'interwovenness' of international organizations and their member States begs the question of who bears responsibility when institutional activity offends international law: for example, when UN peacekeepers violate human rights in carrying out their mandate, when the UN Security Council fails to offer a remedy to blacklisted presumed terrorists, or when an international development bank's lending conditions provoke a member State to, for instance, disrespect international environmental law. 
The law of international responsibility does not have a ready answer to this question. The International Law Commission's ('ILC') 2001 Articles on the Responsibility of States for Internationally Wrongful Acts ('ASR') ${ }^{1}$ intentionally left the question unanswered. The ILC's 2011 Articles on the Responsibility of International Organizations ('ARIO') ${ }^{2}$ attempted to fill this gap by delineating the criteria on the basis of which member States may be found responsible in connection with the acts of international organizations (in particular in Part $\mathrm{V}$ of the ARIO). The ARIO, having laid down the relevant rules on organizational responsibility, have served as the standard of reference regarding the responsibility of member States. They have triggered a lively doctrinal debate, and have been relied upon by a (limited) number of domestic and international courts.

In spite of the adoption and impact of the ARIO, the answer to the question of how precisely responsibility between an international organization and its member States is to be allocated remains an elusive one. This is largely explained by taking the traditional concept of the law of international responsibility and applying it to the independent conduct of States and international organizations, rather than by considering the cooperative or joint conduct involving both an international organization and a member State (or two international organizations, or two or more States, as the case may be). Any effort to determine where the former begins and the latter ends inevitably finds itself at a crossroads involving acts that can be characterized as the State's own conduct, acts that are attributable to both the State and the international organization, or acts which, despite not being attributable to the State, somehow involve its responsibility. In addition, although the current rules of international responsibility envisage the possibility of multiple wrongdoing actors, they arguably lack a clear normative framework on the basis of which responsibility is to be apportioned between member States, as well as between them and the international organization. Inescapably, such indeterminacy will continue to undermine attempts by injured individuals to litigate against wrongdoing member States. Critical procedural questions, such as the immunity of international organizations before domestic courts, and the principle that indispensable third parties should be involved in relevant proceedings, create further obstacles to the attainment of redress.

1 The text of which appears as an annex to General Assembly Resolution 56/83 (12 December 2001), as corrected by UN Doc. A/56/49(Vol. I)/Corr.4, and the commentaries to which appear in Supplement No. 10, UN Doc. A/56/10.

2 Report on the Work of its Sixty-Third Session, un Doc. A/66/10 (2011). The set of 67 draft articles were adopted by the ILC on 3 June 2011, and the commentaries were adopted on 5 August 2011. 
The need for clarification is of course not only felt at the level of the secondary rules of international responsibility. The establishment of member State responsibility is also a question of how to interpret primary norms of international law, and thereby extend their scope of application to the new forms in which States operate at the global level. It is thus fundamental to extract from the discussions on international responsibility indications for a possible harmonized approach to primary legal rules. This helps, for instance, in the determination of how exactly prevention duties condition the operations of troop-contributing States, or how to engage States' human rights duties to protect when they participate in institutional decision-making processes.

Against the backdrop of the ILC's work on international responsibility, this special forum aims to explore recent developments and the remaining conceptual gaps regarding the responsibility of member States of international organizations, and to discuss possible future avenues that may assist in addressing the matters that have been left unregulated by the normative framework so far devised by the ILC. Arguably, at times we allow our minds as legal thinkers to become entangled in what are seemingly insoluble dilemmas of attribution (or the like) within a sphere of intricate power relationships that operate globally, while the problem may also be partly due to constraints in our practical imagination. If institutional law scholarship is on the verge of a mid-life crisis, as feared by Klabbers, ${ }^{3}$ we hope, with this special forum, to offer some sort of therapy.

The special forum, which brings together a distinguished group of renowned scholars and practitioners, seeks to capture the various understandings within academia and legal practice that reflect the evolution of the contemporary law of international (member State) responsibility. It builds on a conference organized under the auspices of the Leuven Centre for Global Governance Studies, with the support of the Flemish Fund for Scientific Research, on 3-4 December 2014 at the Leuven University. ${ }^{4}$ Special thanks are extended to Benjamin Thompson for his editorial assistance.

As will be shown in this special forum, the way we think about international responsibility is not immune to the existence of particular normative interests.

3 Jan Klabbers, 'The Life and Times of the Law of International Organizations' (2001) 70 Nordic Journal of International Law p. 317.

4 The conference website is available at: <https:/ghum.kuleuven.be/ggs/events/2014/ conf-member-state-responsibility>. 
This entails that perspectives - and outcomes - may differ, depending on whether the emphasis is placed on the capacity of member States as States, or on their capacity as members of the international organization (see the contributions in Part I of this special forum). This can be translated into the notion that fluctuations of power between international organizations and their members play a role in various dimensions of international responsibility, and that the transparency of the institutional veil is subject to changes depending on the context (see the contributions in Part II). Given the interconnectedness between member States and international organizations, it may be the case that many situations result in responsibility being shared between both (see the contributions in Part III). This, however, should not hamper the access of individuals to justice, inasmuch as member State responsibility can in any event be scrutinized by national and international courts in its own right (see the contributions in Part IV).

Ramses Wessel and Ige Dekker undertake the enterprise of mapping the different positions and roles member States assume vis-à-vis international organizations. In so doing, they provide an introductory basis upon which to explore this special forum, inasmuch as these differentiations are deemed crucial for the further development of adequate international rules on the responsibility of international organizations and their members. By looking into the different qualities of (member) States in relation to international organizations, and the various functions of the former in exercising institutional tasks, Wessel and Dekker demonstrate that by becoming a 'member State', States do not lose their identity as 'State'; and that even in their identity as a 'member State', States have different roles and functions. Importantly, these various identities are not rigidly fixed, but rather shift on a constant basis, and may even overlap.

Niels Blokker argues that pursuing member State responsibility for the internationally wrongful acts of international organizations may prove to be delusional rather than offer hope to victims. Emphasizing the autonomy and independent legal personality of international organizations, he warns against the dangers of attributing member State responsibility, and posits that member State responsibility should be the exception rather than the rule. Noting that most complaints against member States in fact point to deficiencies at the level of the international organization, he proposes to base dispute-resolution mechanisms with competence over international organizations' responsibility at the level of the international organization itself. This would boost the international organization's legitimacy and increase chances of successful implementation of decisions taken. 
Ana Sofia Barros explores the international responsibility of member States for their own conduct performed as governors of international organizations. This role is derived from member States' particular position of power vis-à-vis international organizations (as 'authority managers'), and essentially translates into a duty of oversight of institutional operations to ensure that these do not run counter to the international law obligations that States are bound to observe. By embracing a victim-centred perspective, she praises the constitutionalist principles of representativeness and responsiveness as necessary requirements guiding the conduct of States: not only in the design of the international organization's operational framework, but also throughout States' participation in its activities. As Barros concludes, a failure by the State to exercise due diligence in these contexts may lead to a finding of member State responsibility.

Catherine Brölmann explores the dynamics of the institutional veil by looking at the various ways in which that notion might engage the responsibility of member States. Characterized by its transparent quality, this analytical tool allows one to look at the position of member States from the outside perspective of general international law, and thereby establish member State responsibility by lifting, permeating or bypassing the institutional veil. As she notes, lifting or permeating the veil to establish the subsidiary responsibility of member States has remained highly contested in legal scholarship and practice, whereas this 'permeation' seems increasingly accepted when it comes to both the attribution of wrongful conduct to member States, and the establishment of the latter's responsibility in connection with wrongful acts of an organization. In other scenarios, the institutional veil is rather bypassed, in which case member States incur responsibility for their own conduct performed in an institutional context.

Jean d'Aspremont suggests an innovative approach to understanding the ARIO, submitting that the adoption of the Articles should be seen as a moment that has led to the empowerment of both international organizations and their member States, rather than one which simply makes them accountable for their actions. The regime of international responsibility is thus not only declaratory of power but also constitutive thereof. What is clear for him is that, in accepting that two types of subjects could be held responsible in relation to institutional activities, the ARIO recognize the flux of power between international organizations and their member States. The ARIO may have stabilized the international responsibility regime with respect to international organizations and their member States, but nevertheless offer sufficiently dynamic tools to keep 
pace with fluctuations of powers, thereby making it possible to arbitrate competing claims of responsibility.

Tom Dannenbaum concentrates on questions of attribution in cooperative military enterprises involving both member States and international organizations. These enterprises have merged systems of authorization, as a result of which it is not always readily clear which conduct is whose. Observing that such collaborative action should nevertheless not evade scrutiny, he hails the effective control standard laid down in Article 7 ARIO, as it attributes conduct to actors who can take preventive action. Analyzing a number of court decisions regarding responsibility in international military operations, he shows that there is a welcome tendency to abandon the presumption that conduct is attributable to the authorizing international organization per se, and instead to inquire into specific conduct carried out in the course of the operation. Such an inquiry may lead to a finding of dual attribution of wrongful conduct to both the international organization and the member State, although this is not inevitable.

Antonios Tzanakopoulos addresses the shared responsibility of the UN and its member States for breaches of the right to fair trial as a result of the application of targeted sanctions against supporters of terrorism. Such sanctions are normatively imposed by the UN Security Council, but are implemented by UN member States (sometimes united in regional organizations, as in the case of the EU). Courts have seized on this implementation to hold member States responsible for rights-violating sanctions. Tzanakopoulos argues, however, that also the UN could and should be held responsible for its member States' acts, as those States, being bound by un Security Council Resolutions, had little discretionary power. The responsibility of the UN could be implemented indirectly through court decisions rendered against member States, as such decisions trigger members to bring pressure to bear on the UN to reform its sanctions regime.

Esa Paasivirta makes the case for treating the EU and its member States differently from other international organizations when it comes to questions of international responsibility. His first main argument relates to the principle that responsibility should follow competence. As he notes, the Eu's modus operandi is unique and difficult to square with the ARIO paradigm, in that the practical application and management of the Eu's legislative and regulatory activity is largely carried out by the national authorities of member States, rather than through the EU's own organs. The EU, where competence lies, 
should thus normally be held responsible, while member State responsibility constitutes the exception. The second differentiating factor relates to the practice of 'mixed agreements', in which both the E U and its member States are parties. As Paasivirta suggests, these agreements bring about a duty of communication on the part of the $\mathrm{EU}$ and its members towards third parties, in view of the need to protect their interests. A failure to do so would lead to the establishment of joint and several responsibility, which the author contends is the default form of responsibility in these cases.

Francesco Messineo turns our attention to mechanisms for invoking the responsibility of member States before national and international courts. Starting from the premise that for every breach of the law a remedy should exist, he observes that litigating member State responsibility is nonetheless not self-evident due to procedural restrictions. He sees merit in suing the respondent State before its own courts, but notes that few domestic courts, with the notable exception of Dutch courts, have been open to such politicallysensitive litigation. In order to expand the range of remedies available to victims, he calls on domestic courts to revise their non-justiciability doctrines, as well as on the international community to allow international organizations to be sued through international dispute-settlement mechanisms.

Paolo Palchetti further develops one of the procedural obstacles that could wreck litigation against member States, namely the "Monetary Gold" principle, by virtue of which a court cannot exercise its jurisdiction if deciding a case against a party may cause it also to determine the legal position of an indispensable third party. Palchetti notes that the application of this doctrine is not entirely fanciful in litigation against member States, notably in ARIO Part V scenarios in which the attribution of responsibility to member States may amount to deciding on the responsibility of the international organization as well. Alive to the reality that victims of institutional action have few remedies available, he proposes to limit the application of the doctrine to scenarios in which derived member State responsibility requires a finding of international wrongfulness by the international organization, and even to exclude it altogether where (international) tribunals have no jurisdiction over international organizations.

Cedric Ryngaert concludes the special forum by integrating its various themes within the overall dialectic inherent in the establishment of member State and international organization responsibility. Conscious of the lack of remedies against international organizations, he notes that the solution does not lie in 
holding member States responsible by virtue of their mere membership. Institutional autonomy is to be preserved, and the rules of international (member State) responsibility, in offering clear attribution criteria, are fundamental in this respect. At the end of the day, victims of institutional action should obtain redress for any harm endured, and member States must not only improve the quality of remedies at the level of the international organization, but also remove the remaining obstacles to litigation concerning the responsibility of member States in domestic courts. 